\title{
Editor's Report for Volume 129 (2015)
}

Mailing dates for issues in volume 129 are as follows: 5 May 2015; 4 August 2015; 23 October 2015; 30 January 2016. A summary of the distribution of memberships in the Ottawa Field-Naturalists' Club, who all receive access to The Canadian Field-Naturalist, and subscribers to The Canadian Field-Naturalist for 2015 is provided in Table 1. Institutional subscribers potentially represent many thousands of users. The number of articles and notes in Volume 129 is summarized in Table 2 by topic. Totals for book reviews and new titles are given in Table 3, and the distribution of content by page totals per issue is provided in Table 4. Sixty-one manuscripts were submitted to The Canadian FieldNaturalist in 2015. Of these, 51 were accepted for publication. A total of 28 Articles, 19 Notes, and 1 Tribute was published in 2015 .

Trina Rytwinski, Assistant Editor, edited content and proofread galleys. We are grateful for the service Trina gave to the journal, and wish her well on her new endeavours. We welcomed Amanda Martin as the journal's new Assistant Editor, who functioned in this role for most of volume 129. Sandra Garland proofed and edited manuscripts. Wendy Cotie typeset galleys, provided corrections for page proofs, and created pdfs; Roy John requested books for review, selected reviewers, edited submitted reviews, and prepared the new titles listings; Jay Fitzsimmons and Ken Young, managed financial accounts, issue mailing and requests for back issues. We thank Jay Fitzsimmons for his contribution as Journal Manager and wish him well on the new phase of his career. We welcomed William Halliday as the new Journal Webmaster. William provided digital content to subscribers, posted tables of contents, abstracts, and pdfs on the CFN website, and prepared the Index with proofreading by Frank Pope. Our Associate Editors managed manuscripts, provided reviews and recommendations, and guided authors through the revisions process. The Publication Committee, chaired by Jeff Saarela and consisting of Paul Catling, Tony Gaston, William Halliday, Karen McLachlan Hamilton, Frank Pope, and David
Seburn effectively guided the operation of the journal. I am indebted to our very dedicated team.

The following Associate Editors managed, assessed and reviewed manuscripts published in volume 129: I. Adams, Cranbrook BC (1); P. M. Catling, Agriculture and Agri-Food Canada, Ottawa ON (5); F. R. Cook, Emeritus Research Associate, Canadian Museum of Nature, Ottawa ON (8); J. Foote, Algoma University, Sault Ste. Marie ON (7); A. J. Gaston, Environment Canada (emeritus), Ottawa ON (5); T. Jung, Yukon Government, Whitehorse YT (3); D. F. McAlpine, New Brunswick Museum, Saint. John NB (1); G. Mowat, Government of British Columbia, Nelson BC (2); D. W. Nagorsen, Mammalia Biological Consulting, Victoria BC (6); M. Obbard, Ontario Ministry of Natural Resources and Forestry, Peterborough ON (1); C. Renaud, Canadian Museum of Nature, Ottawa ON (4); J. M. Saarela, Canadian Museum of Nature, Ottawa ON (5); J. Skevington, Agriculture and Agri-Food Canada, Ottawa ON (1).

The following referees reviewed manuscripts published in volume 129 (number of manuscripts reviewed $>1$ in parentheses): Charles Argue, St. Paul MN; Erik Beever, US Geological Survey; Bruce Bennett, Government of Yukon; Peter Bernhardt, Saint Louis University; Doug Bertram, Environment Canada; Eric Blomberg, University of Maine; Gabriel BlouinDemers, University of Ottawa; Jeff Bowman, Ontario Ministry of Natural Resources (2); Irwin Brodo, Canadian Museum of Nature (emeritus); Rod Brook, Ontario Ministry of Natural Resources and Forestry; Ronald J. Brooks, University of Guelph (emeritus); Donald Brown University of Wisconsin-Madison/ USDA Forest Service; Dan Brunton, Ottawa ON; Jacques Cayouette, Agriculture and Agri-Food Canada; Joseph Buchanan, Washington Department of Fish and Wildlife; Colleen Cassady St. Clair, University of Alberta; Peter Cott, Fisheries and Oceans Canada; Nick Demma, Alaska Department of Fish \& Game; Mark Drever, Environment Canada; Kyle Elliott, McGill University; Scott Findlay, University of Ottawa; David Galbraith, Royal Botanical Garden (2); John Gilhen,

TABLE 1. The 2015 circulation of The Canadian Field-Naturalist (2014 in parentheses). Compiled by Ken Young from the subscription list for 129(4).

\begin{tabular}{lrrrrrrrr}
\hline \hline Subscriber Type & \multicolumn{2}{c}{ Canada } & \multicolumn{2}{c}{ USA } & \multicolumn{2}{c}{ Other } & \multicolumn{2}{c}{ Total } \\
\hline OFNC Members & 61 & $(112)$ & 3 & $(8)$ & 1 & $(1)$ & 65 & $(121)$ \\
Subscriptions: & 12 & $(78)$ & 6 & $(28)$ & 0 & $(3)$ & 18 & $(109)$ \\
$\quad$ Individual & 107 & $(116)$ & 158 & $(167)$ & 19 & $(22)$ & 284 & $(305)$ \\
$\quad$ Institutional & 180 & $(306)$ & 167 & $(203)$ & 20 & $(26)$ & 367 & $(535)$ \\
\hline Total & & & & & & & & \\
\end{tabular}

*Volume 129 figures show a sharp drop from 128 following a cleanup of the subscribers list in 129(1) to remove subscribers who had not paid for some years. 
TABLE 2. Number of research articles and notes published in The Canadian Field-Naturalist, Volume 129, by major field of study.

\begin{tabular}{lccr}
\hline \hline Subject & Articles & Notes & Total \\
\hline Mammals & 7 & 6 & 13 \\
Birds & 7 & 5 & 12 \\
Amphibians and Reptiles & 2 & 3 & 5 \\
Fish & 4 & 2 & 6 \\
Plants & 5 & 2 & 7 \\
Insects & 1 & 0 & 1 \\
Other & 2 & 1 & 3 \\
\hline Total & 28 & 19 & 47 \\
\hline \hline
\end{tabular}

TABLE 3. Number of reviews and new titles published in the Book Review section of The Canadian Field-Naturalist, Volume 129, by topic.

\begin{tabular}{lcc}
\hline \hline & Reviews & New Titles \\
\hline Zoology & 18 & 26 \\
Botany & 3 & 2 \\
Miscellaneous & 14 & 19 \\
\hline Total & 35 & 47 \\
\hline \hline
\end{tabular}

Nova Scotia Museum (emeritus); Scott Gillingwater, Upper Thames River Conservation Authority; JeanFrancois Giroux, Université du Québec à Montréal; Trevor Goward, University of British Columbia; Claire Gower, Montana Fish, Wildlife and Parks; Patrick Gregory, University of Victoria; Arthur Haines, New England Wild Flower Society; Mark Harvey, University of Western Australia; Steve Hecnar, Lakehead University; Philippe Henry, University of Northern British Columbia; Mark Hipfner, Environment Canada; Erling Holm, Royal Ontario Museum; Garrett Hughes, University of Arizona; Mike Jimenez, US Fish and Wildlife Service; Tom Jung, Government of Yukon; Amanda Kahn, University of Alberta; Peter Knamiller, University of Alberta; Erin Koen, Trent University; Kathy Kuletz, US Fish and Wildlife Service; Mark A. Lazzari, Maine Department of Marine Resources; Eric Lofroth, British Columbia Ministry of Environment; Stephen Lougheed, Queens University; Jerry MacDermott, British Columbia Fish and Wildlife Branch; Audrey Magoun, The Wolverine Foundation; Frank Mallory, Laurentian University; Nicholas Mandrak, University of Toronto; Don McAlpine, New Brunswick Museum; Retha Meier, Saint Louis University; Heather Milligan, McGill University; Gail Michener, University of Lethbridge (emeritus); Ken Morgan, Environment Canada;
TABLE 4. Number of pages per section published in The Canadian Field-Naturalist, Volume 129 (2015), by issue.

\begin{tabular}{lrrrrr}
\hline \hline & \multicolumn{5}{c}{ Issue } \\
\cline { 2 - 5 } & 1 & \multicolumn{1}{c}{2} & 3 & 4 & Total \\
\hline Editorials & 0 & 3 & 0 & 0 & 3 \\
Articles & 59 & 66 & 44 & 72 & 241 \\
Notes & 30 & 16 & 30 & 14 & 90 \\
Book Reviews* & 15 & 10 & 14 & 4 & 43 \\
News and Comment, & & & & & \\
$\quad$ Reports** & 3 & 9 & 16 & 7 & 35 \\
Tributes & 7 & 0 & 0 & 0 & 7 \\
Index & - & - & - & 7 & 7 \\
\hline Total & 114 & 104 & 104 & 104 & 426 \\
\hline \hline
\end{tabular}

*Includes reviews and new title listings.

**Includes CFN Editor's report, Minutes of the OFNC

Annual Business Meeting, and OFNC Awards report.

Jan O. Murie, University of Alberta (emeritus); Susan Palta, Wyoming Game and Fish Department; Melanie Percy, Alberta Parks; Gerhard Pohle, Huntsman Marine Science Centre; Kim Poole, Aurora Wildlife Research; Joyce Reddoch, Ottawa; Allan Reddoch, Ottawa; Claude Renaud, Canadian Museum of Nature; Tony Reznicek, University of Michigan; Jim Richards, Orono ON; Helen Schwantje, British Columbia Fish and Wildlife Branch; C. J. Sheivak, New York State Museum (emeritus); Stephen Sjogren, US Fish and Wildlife Service; Doug Smith, US Parks Service; Paul Smith, Environment Canada; James A. Sulikowski, University of New England; Amy Symstad, US Geological Survey; Carl Taylor, Smithsonian Natural History Museum; Paul Venturelli, University of Minnesota Twin Cities; Mark Vinson, US Geological Survey; Andrew Walker, BC Fish and Wildlife Branch.

The journal was printed at Gilmore Printers, Ottawa. Thanks to Mike Datson and Guylaine Duval of Gilmore Printers for overseeing production and printing. I am grateful to Ottawa Field-Naturalists' Club President Fenja Brodo and the club's Board of Directors for their support of the journal. I am also grateful to all of the individual subscribers and authors who support our team as we strive to provide a high-quality scientific journal on natural history. Finally, we thank our families/partners for being patient and supportive throughout many evenings and weekends of working on the journal.

Carolyn Callaghan, Editor in Chief; AMANDA MARTIN, Assistant Editor 